\title{
ОСОБЛИВОСТІ ЦИТОКІНОВОГО ПРОФІЛЮ У СИРОВАТЦІ КРОВІ ЩУРІВ ЗА УМОВИ КОРЕКЦІЇ ТРАВМИ М'ЯЗІВ ПЛАЗМОЮ КРОВІ, ЗБАГАЧЕНОЮ ТРОМБОЦИТАМИ
}

\section{Особливості цитокінового профрілю у сироватці крові щурів за умови корекції травми м'язів плазмою крові, збагаченою тромбоцитами \\ В. Г. Дживак, І. М. Кліщ \\ Тернопільський національний медичний університет імені І. Я. Горбачевського МОЗ України}

Резюме. Плазма крові, збагачена тромбоцитами, набула великої актуальності в останнє десятиліття i становлять все більшу спрямованість експериментального та клінічного дослідження в контексті загоєння ран та регенерації тканин. Однак незважаючи на різноманітні програми, ефрективність регенеративних методів лікування плазмою крові, збагаченою тромбоцитами, залишається актуальною.

Мета дослідження - оцінити ефективність плазми крові, збагаченої тромбоцитами, на показники цитокінового профрілю за умови експериментальної травми м'язів.

Матеріали і методи. Експериментальне дослідження виконано на 92 нелінійних білих щурах. Травму моделювали за розробленою методикою в умовах тіопентал-натрієвого знеболюванняння. Отримання плазми, збагаченої тромбоцитами, відбувалося у два етапи 3 дотриманням усіх правил стерильності. Визначали вміст цитокінів сироватки крові (TNF $\alpha$, IL1 $\beta$, IL6, IL10) методом твердофразового імунофрерментного аналізу.

Результати. Показники прозапальних цитокінів сироватки крові у щурів, яким моделювали травму м'язів, були достовірно вищими, ніж у тварин без змодельованої патології. Застосування плазми крові, збагаченої тромбоцитами, супроводжувалось зменшенням концентрації прозапальних цитокінів сироватки крові. Порівнюючи отримані дані до та після корекції, можна зробити висновок щодо протизапального ефректу PRP, який характеризувався зниженням концентрації прозапальних цитокінів, які посилено продукуються при запальному процесі у відповідь на травму м'язів у всі терміни спостереження, та гіперпродукцією протизапального IL 10, який може пригнічувати вироблення TNF $\alpha$ та послаблювати його негативні ефректи.

Висновки. У тварин з механічною травмою м'язів стегна спостерігається підвищення концентрації IL1 $\beta$, TNF $\alpha$ та IL6 сироватки крові на тлі виснаження протизапальних резервів. Застосування плазми, збагаченої тромбоцитами, зменшує прозапальний ефект цитокінів шляхом зниження їх концентрації, починаючи з першої доби експерименту.

\section{Peculiarities of serum cytokine profile in rats in muscle injury during platelet-rich plasma correction}

V. H. Dzhyvak, I. M. Klishch

I. Horbachevsky Ternopil National Medical University

e-mail: djyvak@tdmu.edu.ua

Summary. Platelet-rich plasma have become increasingly relevant in the last decade and are increasingly the focus of experimental and clinical research in the context of wound healing and tissue regeneration. However, despite various programs, the effectiveness of regenerative methods of treatment of platelet-rich blood plasma remains relevant.

The aim of the study - to evaluate the efficacy of platelet-rich plasma on cytokine profile in the setting of experimental muscle injury.

Materials and Methods. The experimental study was performed on 92 nonlinear white rats. The injury was modeled according to the developed method in the conditions of thiopental-sodium anesthesia. Obtaining platelet-rich plasma occurred in two stages with all the rules of sterility. Determination of serum cytokines (TNF $\alpha, I L 1 \beta$, IL6, IL10) by solid-phase enzyme-linked immunosorbent assay.

Results. Serum proinflammatory cytokines in rats muscle injury were significantly higher than in animals without simulated pathology. The use of platelet-rich blood plasma (PRP) was accompanied by a decrease in the concentration of proinflammatory serum cytokines. Comparing the data obtained before and after correction, we can conclude about the anti-inflammatory effect of PRP, which was characterized by a decrease in the concentration of proinflammatory cytokines, which are strongly produced in the inflammatory process in response to muscle injury at all times, and hyperproduction of anti-inflammatory IL10, which can inhibit TNF $\alpha$ production and mitigate its negative effects.

Conclusions. Thus, in animals with mechanical injury to the thigh muscles, there is an increase in the concentration of IL1 $\beta$, TNF $\alpha$ and IL6 in the serum against the background of depletion of anti-inflammatory reserves. The use of PRP reduces the proinflammatory effect of cytokines by reducing their concentration from the first day of the experiment. 
Ключові слова: травма м'язів; цитокіни; плазма, збагачена тромбоцитами.

\section{ВСТУП}

Скелетні м'язи є найпоширенішою тканиною в організмі людини, яка становить близько $40 \%$ маси тіла. У повсякденному житті відбувається часте їх ушкодження, зокрема механічні травми, термічний стрес, ішемія, дія різних патогенних чинників [1].

За умови травми м'язів руйнується цілість плазматичної мембрани міоволокна та базальної пластинки, що веде до зростання в клітині рівня позаклітинного кальцію та у підсумку призводить до деградації м'язових білків та некрозу [2]. Клітини запалення, які сприяють очищенню та відновленню некротичної тканини, домінують у місцевій реакції на ушкодження [3]. Ці клітини вивільняють розчинні молекули, головним чином, цитокіни, які, як правило, фрункціонують як міжклітинні месенджери в аутокринному режимі, зв'язуючись із клітиною свого походження, або в паракринному режимі, та із рецепторами сусідньої клітини-мішені [4]. Оскільки цитокіни діють не тільки локально, тому місцеве запалення супроводжується системною реакцією. При цьому за умови значного ушкодження м'язів порушення балансу між про- та протизапальною реакцією може спричинити генералізовану відповідь, яка, у свою чергу, може зумовити поліорганну недостатність [5].

У механізмах індукції загоєння м'язової тканини плазмою крові (PRP), збагаченою тромбоцитами, основну ффункцію виконують фрактори росту, яких на даний час дуже багато: тромбоцитарний фрактор росту, трансорормуючий фрактор росту-1, тромбоцитарний фрактор ангіогенезу, інсуліноподібний фрактор росту, остеокальцин, остеонектин, орібриноген та інші [6-9]. Їх дія проявляється локально за рахунок залучення недиференційованих клітин до нового сформованого матриксу і запуску клітинного ділення в ділянці ушкодження. Однак ці механізми потребують уточнення та додаткового вивчення.

Таким чином, використання плазми, збагаченої тромбоцитами, в експериментальних та клінічних дослідженнях в контексті загоєння ран та регенерації тканин є актуальною в останнє десятиліття. Однак незважаючи на різноманітні програми, ефективність регенеративних методів лікування PRP залишається актуальною.

Метою дослідження було оцінити ефективність плазми крові, збагаченої тромбоцитами, на показники цитокінового профрілю за умови експериментальної травми м'язів.
Key words: muscle injury; cytokines; platelet-rich plasma.

\section{МАТЕРІАЛИ I МЕТОДИ}

Експериментальне дослідження виконано на 92 нелінійних білих щурах масою 180-210 г, яких утримували на стандартному раціоні віварію Центральної науково-дослідної лабораторії. Тварин поділили на 3 групи: контрольна - 12 щурів (інтактні), перша дослідна група з травматичним ураженням м'язів стегна без введення PRP (40 щурів), друга дослідна група - 3 травматичним ураженням м'язів стегна та введенням PRP (40 щурів). Tравму моделювали за розробленою методикою в умовах тіопентал-натрієвого знеболювання (40 мг/кг) згідно з Конвенцією [10]. На час евтаназії кількість тварин була меншою у зв'язку із загибеллю в процесі експерименту. Робота була проведена на базі Центральної науково-дослідної лабораторії (свідоцтво про атестацію № 001/18 від 26 вересня 2018 року) та міжкафедральної навчально-дослідної лабораторії (свідоцтво про атестацію № 132/17 видане 29 грудня 2017 року) Тернопільського національного медичного університету імені І. Я. Горбачевського МОЗ України.

При роботі з тваринами дотримувались правил поводження 3 експериментальними тваринами згідно $з$ Директивою Ради ЄC 2010/63/EU про дотримання постанов, законів, адміністративних положень Держав ЄС 3 питань захисту тварин, які використовуються для наукової мети [11].

Для дослідження використовували сироватку крові. Тварин декапітували під тіопенталовим наркозом на 1-шу, 7-му, 14-ту і 21-шу доби після нанесення травми.

Визначення вмісту цитокінів сироватки крові (TNFa, IL1 $\beta$, IL6, IL10) проводили на аналізаторі «Multiscan FC» (Thermo Scietific, Фінляндія) методом твердофразового імунофрерментного аналізу 3 використанням наборів реагентів «RayBio» виробництва «RayBiotech» (США).

Брали плазму, збагачену тромбоцитами, у два етапи 3 дотриманням усіх правил стерильності. Починали $з$ отримання крові білих щурів, яку отримали шляхом пускання з серця у пробірку із антикоагулянтом у співвідношенні кров : антикоагулянт - 9 : 1, та поміщали у лабораторну центрифругу LMC-3000 «Biosan» (Латвія).

Перше центрифругування проводили упродовж 10 хв для осадження еритроцитів та лейкоцитів зі швидкістю 1600 об./хв. Друге центрифругування було проведене зі швидкістю 2100 об./хв - 10 хв.

Статистичну обробку цифрових даних здійснювали за допомогою програмного забезпечення Excel та STATISTICA 3 використанням параметричних і непараметричних методів оцінки 
отриманих даних. Для всіх показників розраховували значення середньої арифметичної вибірки (M), її дисперсії і помилки середньої (m). Достовірність різниці значень між незалежними кількісними величинами визначали при нормальному розподілі за t-критерієм Стьюдента, в інших випадках - за допомогою U-критерію Манна - Уїтні (достовірним вважали відмінності при р<0,05).

\section{РЕЗУЛЬТАТИ Й ОБГОВОРЕННЯ}

Показники прозапальних цитокінів сироватки крові у щурів, яким моделювали травму м'язів, були достовірно вищими, ніж у тварин без змодельованої патології. Так, концентрація IL1ß на 1 добу після нанесення травми була достовірно вищою від показника тварин без змодельованої патології у 2,4 раза. Аналогічні зміни були відмічені й стосовно інших прозапальних цитокінів. Зокрема, показник TNFa у цей термін спостереження був у 2,6, a IL6 - в 2,4 раза вищим, ніж у тварин, яким травми не моделювали. В обох випадках різниця між показниками була достовірною. На 7 добу концентрація IL1ß дещо знизилася, однак перевищувала рівень тварин без змодельованої патології у 1,8 раза. Зміни показників TNF $\alpha$ та IL6 мали аналогічну спрямованість і на 7-му добу від моменту нанесення травми перевищували відповідно у 2,0 й 1,9 раза показники тварин без змодельованої патології. До 14-ї доби концентрація досліджуваних прозапальних цитокінів залишалася практично на тому ж рівні, що й у попередній термін спостереження, однак все ж вірогідно перевищували рівень тварин без змодельованої патології. До 21-ї доби концентрації досліджуваних прозапальних цитокінів сироватки крові зменшувались, проте були достовірно вищими від норми, зокрема концентрація IL1 $\beta$ в 1,6 раза, TNF $\alpha$ - у 1,4 раза та IL 6 - в 1,3 раза (табл.).

Аналізуючи динаміку зміни концентрації прозапальних цитокінів, варто відмітити їх односпрямованість, зокрема максимальне зростання на першу добу, незначне зниження та коливання практично на одному рівні протягом 7-14 діб та зниження до 21 доби (рис.).

Концентрація протизапального IL10 вірогідно зростала на 1 добу (в 1,6 раза), тоді як на 7 добу зменшувалась, статистично значимо не відрізняючись від показників інтактної групи. Варто зазначити, що на 14 добу концентрація даного цитокіну була менша в 1,5 раза стосовно даних тварин без змодельованої патології і залишалася практично на тому ж рівні, що й у попередній термін спостереження, до 21 доби (табл.).

За даними П. М. Чорноморець та Н. Є. Нурищенко, специфрічною особливістю м'язового запалення $€$ здатність самих м'язових волокон до секреції медіаторів запалення, зокрема IL1ß,
TNFa тa IL6, які $€$ хемотактичними агентами для нейтрофрілів та інших імунокомпетентних клітин, унаслідок чого лейкоцити мігрують до ушкодженої ділянки м'яза та зумовлюють розвиток запалення [12]. Патогенетично необхідно відмітити гіперпродукцію активних орорм оксигену нейтрофрілами та активацію процесів вільнорадикального окиснення у локусі запалення, що $є$ типовим патологічним процесом та ключовим ушкоджувальним чинником $[13,14]$.

Застосування плазми крові, збагаченої тромбоцитами, супроводжувалось зменшенням концентрації прозапальних цитокінів сироватки крові. Така плазма містить фрібрилярний і клітинний компоненти та здатна діяти як носій клітин, які важливі для регенерації м'яких і кісткових тканин [15]. Так, концентрація IL1 $\beta$ на 1-шу добу від моменту нанесення травми у тварин цієї групи перевищувала рівень тварин без змодельованої патології в 1,8 раза, однак була на 29,3 \% меншою, ніж у тварин, яким моделювали травму, але корекції не проводили. Концентрація TNFa також перевищувала рівень здорових тварин у 2,1 раза, що, однак на 21,0 \% менше, ніж у тварин без корекції. Аналогічну спрямованість мала також концентрація IL6 - показник був 1,8 раза вищим, ніж в нормі, проте меншим від рівня тварин без змодельованої патології - на 29,6\%.

На 7-му добу експерименту не спостерігалось нормалізації прозапальних цитокінів. Зокрема, концентрація IL1ß була вищою від показника тварин без змодельованої патології в 1,5 раза та на 20,4 \% меншою, ніж аналогічний показник тварин без корекції. Концентрація TNFa та IL6 за спрямованістю була майже аналогічною до показника IL1 $\beta$, перевищуючи норму відповідно в 1,7 та 1,6 раза, причому обидва показники були достовірно меншими, ніж у травмованих тварин, яким корекцію не проводили - на 21,8 та 19,0 \% відповідно. Варто відмітити, що на 14 добу після PRP-корекції концентрація прозапальних цитокінів практично не відрізнялася від даних попередньої групи спостереження.

Більш виражене зниження прозапальних цитокінів ми встановили на 21 добу експерименту. Так, у цей термін спостередження концентрація IL1 $\beta$, TNF $\alpha$ та IL6 перевищувала рівень тварин без змодельованої патології в 1,2 раза. При цьому концентрація TNFa та IL6 була відповідно на 30,5; 21,9 \% меншою, ніж у травмованих тварин без корекції (табл.).

Застосування плазми крові, збагаченої тромбоцитами, супроводжувалось вірогідним підвищенням концентрації IL10 стосовно тварин без змодельованої патології та травмованих тварин, яким корекцію не проводили на першу добу експерименту. На 7-му добу досліджуваний показник
Вісник медичних і біологічних досліджень Bulletin of Medical and Biological Research
$3(5), 2020$ 
Таблиця. Динаміка показників цитокінового профрілю сироватки крові щурів із м'язовою травмою та корекцією PRP $(\mathrm{M} \pm \mathrm{m})$

\begin{tabular}{|c|c|c|c|c|c|}
\hline \multirow{2}{*}{\multicolumn{2}{|c|}{ Група тварин }} & \multicolumn{4}{|c|}{ Показник } \\
\hline & & IL1ß, пг/мл & TNFa, пг/мл & IL6, пг/мл & IL10, пг/мл \\
\hline \multicolumn{2}{|c|}{ Без патології (n=12) } & $5,20 \pm 0,16$ & $4,64 \pm 0,23$ & $4,40 \pm 0,14$ & $11,50 \pm 0,29$ \\
\hline \multirow{4}{*}{$\begin{array}{c}\text { Перша група } \\
\text { (травма без } \\
\text { PRP) }\end{array}$} & перша доба (n=9) & $12,37 \pm 0,25^{\star}$ & $12,17 \pm 0,27^{*}$ & $10,41 \pm 0,18^{*}$ & $18,52 \pm 0,29^{*}$ \\
\hline & сьома доба $(\mathrm{n}=8)$ & $9,43 \pm 0,21^{*}$ & $9,38 \pm 0,23^{*}$ & $8,39 \pm 0,18^{*}$ & $11,31 \pm 0,28$ \\
\hline & чотирнадцята доба $(\mathrm{n}=8)$ & $9,90 \pm 0,27^{*}$ & $8,93 \pm 0,18^{*}$ & $8,13 \pm 0,23^{*}$ & $7,80 \pm 0,29^{*}$ \\
\hline & двадцять перша доба (n=7) & $8,43 \pm 0,26^{*}$ & $6,69 \pm 0,24^{*}$ & $5,74 \pm 0,19 *$ & $8,01 \pm 0,18^{*}$ \\
\hline \multirow{4}{*}{$\begin{array}{c}\text { Друга група } \\
\text { (травма } \\
\text { з PRP) }\end{array}$} & перша доба $(\mathrm{n}=9)$ & $9,57 \pm 0,13^{\star \#}$ & $10,06 \pm 0,15^{\text {*\# }}$ & $8,03 \pm 0,09$ *\# & $19,41 \pm 0,18^{\star \#}$ \\
\hline & сьома доба $(\mathrm{n}=9)$ & $7,83 \pm 0,12^{\star \#}$ & $7,70 \pm 0,20$ *\# & $7,05 \pm 0,16^{\star \#}$ & $12,73 \pm 0,33^{\star \#}$ \\
\hline & чотирнадцята доба (n=8) & $7,34 \pm 0,17^{\text {*\# }}$ & $7,15 \pm 0,12^{\text {*\# }}$ & $6,84 \pm 0,11^{\text {*\# }}$ & $11,04 \pm 0,17^{\#}$ \\
\hline & двадцять перша доба (n=8) & $6,46 \pm 0,11^{\text {*\# }}$ & $5,49 \pm 0,14^{\star \#}$ & $5,26 \pm 0,12^{\star \#}$ & $11,29 \pm 0,18$ \\
\hline
\end{tabular}

Примітки: 1) * - зміни показників достовірні відносно інтактних $(p<0,05)$;

2) \# - зміни показників тварин із корекцією достовірні відносно показників без корекції на відповідні доби дослідження (р<0,05),

знижувався в 1,1 раза відносно даних травмованих тварин, яким корекцію не проводили, проте був вірогідно вищим даних інтактної групи, тоді як у наступні терміни спостереження (14 і 21 доби) практично не відрізнявся від контрольної групи (табл.).

Порівнюючи отримані дані до та після корекції, можна зробити висновок щодо протизапального есректу PRP, який характеризувався зниженням концентрації прозапальних цитокінів, які посилено продукуються при запальному процесі у відповідь на травму м'язів у всі терміни спостереження, та гіперпродукцією протизапального IL 10, який може пригнічувати вироблення TNFa та послаблювати його негативні ефректи (рис.).

За даними P. Bendinelli et al. (2010), протизапальний ефект PRP реалізується шляхом редукції експресії COX2- і CXCR4-генів, які беруть участь у реакціях запалення [7]. При цьому інші наукові дані засвідчують аналгетичні властивості PRP, їx здатність зменшувати набряки м'яких тканин при травмах різного генезу, вплив на ангіогенез та неоваскуляризацію [16-18].

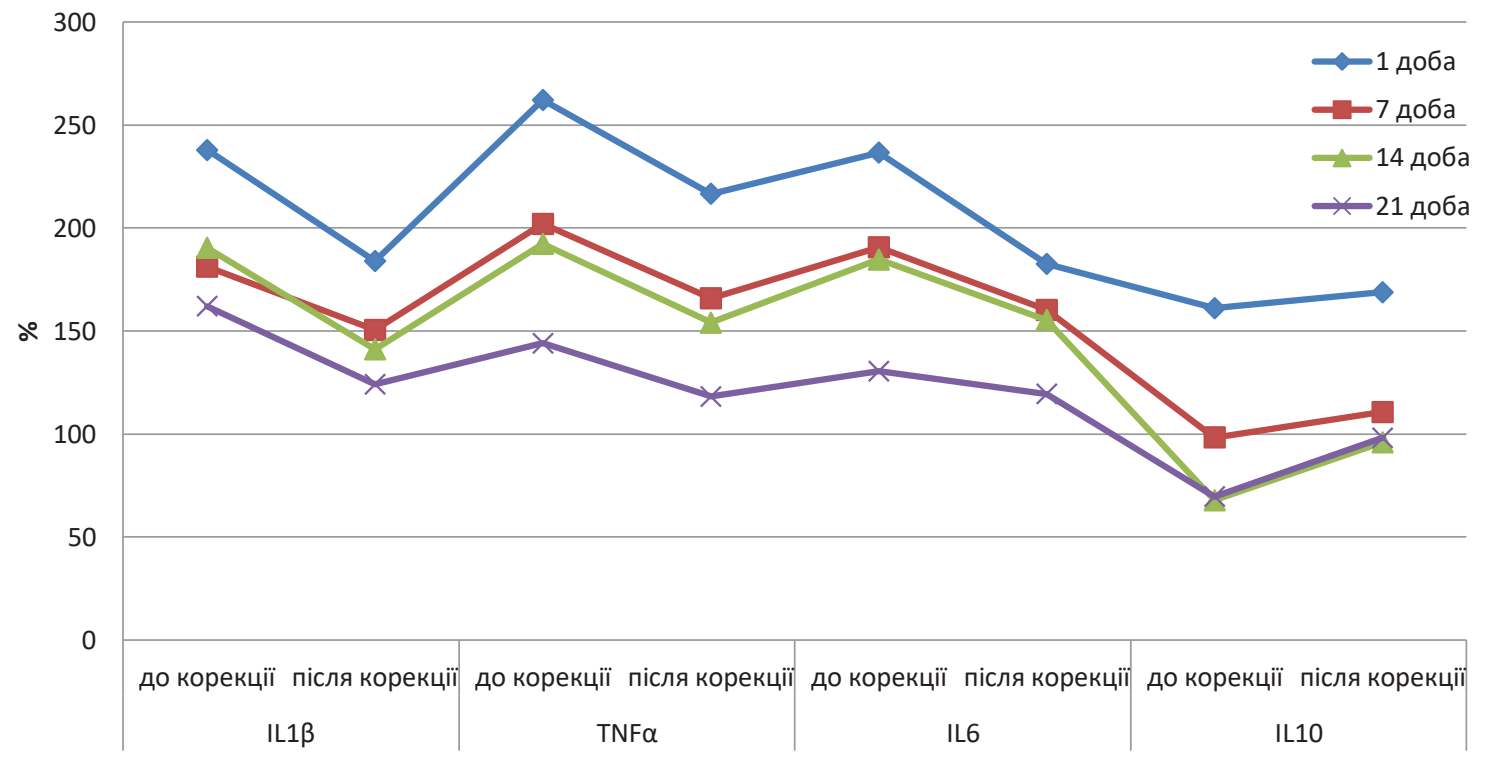

Рис. Зіставлення показників цитокінового профілю сироватки крові щурів із м'язовою травмою та корекцією PRP.

\section{ВИСНОВКИ}

У тварин з механічною травмою м'язів стегна спостерігається підвищення концентрації IL1ß, TNF $\alpha$ та IL6 сироватки крові (з максимумом на першу добу) на тлі виснаження протизапальних резервів (зниження концентрації IL10 з 14 доби експерименту). Застосування плазми, збагаченої тромбоцитами, зменшує прозапальний ефект цитокінів шляхом зниження їх концентрації, починаючи з першої доби експерименту. 


\section{СПИСОК ЛІТЕРАТУРИ}

1. Fernandes T. L. Muscle injury - physiopathology, diagnosis, treatment and clinical presentation / T. L. Fernandes, A. Pedrinelli, A. J. Hernandez // Rev. Bras. Ortop. - 2011. - No. 46 (3). - P. 247-255.

2. Yang W. Skeletal muscle regeneration is modulated by inflammation / W. Yang, P. Hu // Journal of Orthopaedic Translation. - 2018. - No.13. - P. 25-32.

3. Tidball J. G. Inflammatory processes in muscle injury and repair / J. G. Tidball // Am. J. Physiol. Regul. Integr. Comp. Physiol. - 2005. - No. 288. - P. 345-353.

4. Changes in serum cytokines in response to musculoskeletal surgical trauma / O. Reikeras, P. Borgen, J. E. Reseland [et al.] // BMC Res. Notes. - 2014. - No. 7 (128).

5. Diagnosis-dependent relationships between cytokine levels and survival in patients admitted for surgical critical care / T. Hranjec, B. R. Swenson, L. A. Dosset [et al.] // J. Am. Coll. Surg. - 2010. - No. 210. - P. 833-844.

6. Ахмеров Р. Плазмолифтинг (Plasmolifting) - лечение возрастной атрофии кожи, богатой тромбоцитами аутоплазмой / Р. Ахмеров, Р. Зарудий, И. Рычкова // Эстетическая медицина. - 2011. - № 10 (2). - С. 3-9.

7. Molecular basis of anti-inflammatory action of plateletrich plasma on human chondrocytes: mechanisms of NF-kappa B inhibition via HGF / P. Bendinelli, E. Matteucci, G. Dogliotti [et al.] // J. Cell Physiol. - 2010. - Vol. 225. P. 757-766.

8. Jin R. Does platelet-rich plasma enhance the survival of grafted fat? An update review / R. Jin, L. Zhang, Y. Zhang // Int. J. Clin. Exp. Med. - 2013. - Vol. 6 (4). - P. 252-258.

9. Kakudo N. Proliferation-promoting effect of plateletrich plasma on human adipose-derived stem cells and human dermal fibroblasts / N. Kakudo, T. Minakata, T. Mitsui // Plast. Reconstr. Surg. - 2008. - Vol. 22. - P. 1352-1360.

10. European convention for the protection of vertebrate animals used for experimental and other scientific purposes. - Council of Europe. Strasbourg. - 1986. - No. 123. - 52 p.
11. Directive 2010/63/EU of the European Parliament and of the Council of 22 September 2010 on the protection of animals used for scientific purposes // Official Journal of the European Union. - 2010. - Vol. 276. - P. 33-79.

12. Чорноморець П. М. Запалення при м'язовій травмі: пошкоджуюча та відновлювальна дія / П. М. Чорноморець, Н. Є. Нурищенко // Фізика живого. - 2008. T. 16 (1). - C. 171-174.

13. Марущак М. И. Система фрактора некроза опухолей альфа в патогенезе экспериментального острого поражения легких / М. И. Марущак // Туберкулез, легочные болезни, ВИЧ-инфекция. - 2012. - № 2. - С. 27-31.

14. Марущак М. І. Закономірності змін цитокінового статусу в бронхоальвеолярному змиві щурів за умови гострого ураження легень / М. І. Марущак // Шпитальна хірургія. - 2012. - № 2. - С. 39-42.

15. Івченко Д. В. Застосування аутологічної плазми, що збагачена тромбоцитами, для оптимізації репаративної регенерації кісткової тканини при остеопенії / Д. В. Івченко, В. В. Мірошніков // Патологія. - 2018. № 2 (43). - C. 248-258.

16. Липова Е. В. Аутологичная тромбоцитами плазма в лечении эрозивно- язвенных поражений кожи / Е. В. Липова, К. А. Покровский, Н.В.Просянникова // Экспериментальная и клиническая дерматокосметология. - 2013. - № 4. - С. 48-52.

17. Treatment of chronic non-healing ulcers using autologous platelet rich plasma: a case series / M. Suthar, S. Gupta, S. Bukhari [et al.] // Biomed. Sci. - 2017. No. 1. - P. 16

18. The influence of patient and wound variables on healing of venous leg ulcers in a randomized controlled trial of growth-arrested allogeneic keratinocytes and fibroblasts / J. C. Lantis 2nd, W. A. Marston, A. Farber [et al.] // J. Vasc. Surg. - 2013. - No. 2. - P. 433-439.

- treatment of age-related skin atrophy with platelet-rich autoplasma]. Esteticheskaya meditsina. 2011;10(2): 3-9. Russian.

7. Bendinelli P, Matteucci E, Dogliotti G, Corsi MM, Banfi G, Maroni P, Desiderio MA. Molecular basis of anti-inflammatory action of plateletrich plasma on human chondrocytes: mechanisms of NF-kappa B inhibition via HGF. J Cell Physiol. 2010;225: 757-66.

8. Jin R, Zhang L, Zhang Y. Does platelet-rich plasma enhance the survival of grafted fat? An update review. Int J Clin Exp Med. 2013;6(4): 252-8.

9. Kakudo N, Minakata T, Mitsui T. Proliferationpromoting effect of platelet-rich plasma on human adiposederived stem cells and human dermal fibroblasts. Plast Reconstr Surg. 2008;22: 1352-60.

10. European convention for the protection of vertebrate animals used for experimental and other scientific purposes. Council of Europe. Strasbourg. 1986. 
11. Directive 2010/63/EU of the European Parliament and of the Council of 22 September 2010 on the protection of animals used for scientific purposes // Official Journal of the European Union. - 2010. - L276. - P. 33-79.

12. Chornomorets PM, Nurishchenko NE. [Inflammation in muscle injury: damaging and repairing effect]. Fizyka zhyvoho. 2008;16(1): 171-4. Ukrainian.

13. Marushchak MI. [Tumor necrosis factor alpha system in the pathogenesis of experimental acute lung injury]. Tuberkulez, legochnyye bolezni, VICH-infektsiya. 2012;2: 27-31. Russian.

14. Marushchak MI. [Regularities of changes in cytokine status in bronchoalveolar lavage of rats under conditions of acute lung injury]. Shpytalna khirurhiia. 2012;2: 39-42. Ukrainian.
15. Ivchenko DV, Miroshnikov VV. [The use of autologous plasma, enriched in platelets, to optimize the reparative regeneration of bone tissue in osteopenia]. Patolohiia. 2018;2(43): 248-58. Ukrainian.

16. Lipova EV, Pokrovsky KA, Prosyannikova NV. [Autologous platelet plasma in the treatment of erosive and ulcerative skin lesions]. Eksperimentalnaya i klinicheskaya dermatokosmetologiya. 2013;4: 48-52. Russian.

17. Suthar M, Gupta S, Bukhari S, Ponemone V. Treatment of chronic non-healing ulcers using autologous platelet rich plasma: a case series. Biomed Sci. 2017;1:16.

18. Lantis 2nd JC, Marston WA, Farber A, Kirsner RS, Zhang Y, Lee TD, Cargill DI, et al. The influence of patient and wound variables on healing of venous leg ulcers in a randomized controlled trial of growth-arrested allogeneic keratinocytes and fibroblasts. J Vasc Surg. 2013;2: 433-9.

Отримано 10.08.20 